Author version: Mar. Geol., vol.276(1-4); 2010; 58-70

\title{
Bathymetric Highs in the mid-slope region of the Western Continental Margin of India - Structure and Mode of origin
}

\author{
D. Gopala Rao*, A.L. Paropkari**, K.S. Krishna**, A.K. Chaubey**, K.K. Ajay** and V.N. Kodagali** \\ * Geology Department, Osmania University, Hyderabad - 500007, India. \\ ** National Institute of Oceanography, Dona Paula, Goa - 403 004, India.
}

\begin{abstract}
Analysis of the multi- and single beam bathymetric, seismic, magnetic and free-air gravity (ship-borne and satellite derived) data from the western continental margin of India between $12^{\circ} 40^{\prime} \mathrm{N}$ and $15^{\circ} \mathrm{N}$ had revealed the presence of several flat topped NNW-SSE trending bathymetric highs of considerable areal extent, 256 to $1165 \mathrm{~km}^{2}$ area each at base. They are interspersed by bathymetric lows, thereby, forming a chain of horst and graben structures covered by thick sediments. 2-D modeling of the gravity and magnetic anomalies constrained by seismic results (reflection and refraction) had indicated $\sim 23 \mathrm{~km}$ thick crust consisting of 2 to $3 \mathrm{~km}$ thick sediments, and a thin basaltic and granitic layer. The model has brought into focuss the presence of mantle based volcanic plugs Their geomorphological and geophysical expressions and structural pattern and associated deep-seated faults led to suggest continental crust. These features are inferred as rifted fragments of the western continental margin of India formed during its northward movement. They were subjected to sub-aerial erosion during the Paleogene due to lowered sea levels resulting in flat tops Subsequently they were submerged to the present depths in the Neogene. The basic tectonic process appears to be regional.
\end{abstract}

Key words: Western continental margin of India, Prathap Ridge, Bathymetric Highs, Kori-Comorin Ridge, Tectonics, Crustal Structure.

*Corresponding Author: D. Gopala Rao (e-mail: drgopalarao@yahoo.com)

Fax: 91-40-27171564; Phone 91-9440911293 


\section{Introduction}

Geological and geophysical investigations of the western continental margin of India revealed the presence of several structures-- bathymetric highs and lows, buried basement ridges, sediment filled grabens etc. Their origin and the nature of crust are speculative. The highs and lows occur in 245 to $1600 \mathrm{~m}$ water depths of the southwest continental margin of India between the Mormugoa $\left(\sim 15^{\circ} \mathrm{N}\right)$ and Kochi $\left(\sim 11^{\circ} \mathrm{N}\right)$ coasts. In the study area, $12^{\circ} 40^{\prime} \mathrm{N}$ to $15^{\circ} \mathrm{N}$ (Fig.1) the continental margin differs from the typical passive continental margin structural style, especially in the slope region owing to presence of the flat topped bathymetric highs, A to $\mathrm{E}$.

Fig.1

The basement highs in $2000 \mathrm{~m}$ water were seismically imaged (Naini and Talwani, 1982) and considered as part of Prathap Ridge formed by the trail of igneous activity of the Reunion Hot--spot (Krishna et al., 1994). They were interpreted as part of the NNW-SSE trending Kori-High at the outer shelf of the Kachchh--Kathiawar coasts (between $23^{\circ} 51^{\prime} \mathrm{N}$ and $21^{\circ} 30^{\prime} \mathrm{N}$ ) in 200-500 m water and Comorin Ridge in $\sim 2000 \mathrm{~m}$ water of the shelf margin basin south of the south west coast $\left(\sim 0^{\circ} \mathrm{N}\right)$ (Biswas, 1988; Biswas and Singh, 1988). Both of them are carpeted by thick terrigenous sediments, distant apart and discrete. This led to a suggestion that the Kori-Comorin Ridge probably exists in the shelf margin basin parallel to the west coast of India, lying to the east of the Prathap Ridge. Seismic images of parts of igneous Prathap Ridge (Naini and Talwani, 1982; Subrahmanya, 1987; Chaubey et al., 2002) have depicted inverted ' $V$ ' shaped basement rises/high structures of high impedance contrast with overlying sediments with clear hyperbolic reflections of vertices at varied depths. Chakraborty et al. (2006) have suggested that some of the marginal highs are volcanic extrusions. Gopala Rao et al. (1987) have reported correlation between a bathymetric high and a positive magnetic anomaly in the southern profile of Kochi coast in the south $\left(-11^{\circ} \mathrm{N}\right)$. Whereas such a correlation could not be established on the northern profiles of Marmugao--Mangalore coasts. This was attributed to compositional heterogeneity or greater depths of the highs. If the Prathap Ridge and the marginal highs have formed by the same igneous activity associated with the Reunion Hotspot, one would expect distinct similarities among their geophysical signatures, crustal structure, geographic disposition and geomorphic expression. In this scenario to resolve various issues, multi-beam swath bathymetric data acquired during cruises of research vessel ORV Sagar Kanya (SK-65, SK-114 and SK-158) along with seismic, magnetic and gravity data covering most of the highs have been analyzed to examine the structure and nature of the crust, origin and the genetic relationship with the basement rises constituting the Prathap Ridge of the shelf margin basin and the Kori-Comorin Ridge. 


\section{Data:}

The present investigations include multi-beam bathymetry, seismic (single and multi-channel), free-air (ship-borne and satellite derived) gravity, magnetic data collected during several cruises and published refraction results in the study area. A free-air gravity anomaly map (Fig. 2) at 20 mGal contour interval was constructed from the 1'x1' satellite derived gravity data base of Sandwell and Smith (1997). Both buried and exposed structures especially the numerous parallel chains of anomalies clusters of NE-SW trends (marked by dashed lines) are well reflected in the satellite free-air gravity anomaly map.

\section{(Fig. 2).}

\section{Table.1}

A bathymetric map of the multi-beam data (Fig.3) has been prepared after duly filtering the noise and applying slant range and salinity corrections to the data. Plots of total magnetic

Fig.3

intensity (after duly correcting), free-air gravity anomalies and seismic images along the profiles have also been prepared along with the bathymetry (Figs 4 to 9). The profiles A-A', B-B' and $B_{1}-B_{1}$ ' and F-F' are across the bathymetric highs $A, B$, and $E$ respectively. The

Figs 4 to 7

seismic profiles G-G' and H-H' (Fig. 8 and 9) are across the bathymetric 'lows' in between

Fig. 8 and 9

the highs. Geomorphic expressions and geophysical signatures of the highs are listed (Table1). Velocity and depth sections (Fig 10 and Table. 2) are also prepared from

Fig. 10 and Table. 2

published data (Naini and Talwani, 1982) at sonobouy stations 85c17, L08, L12 and 72V (Fig.1) from the offshore and refraction data of adjoining onshore areas (Kaila et al.,1979). A two dimensional model of the crust modeled from gravity and magnetic anomalies of the profile B1-B1'and constrained by the seismic results from the close by profile B-B' is also presented (Fig. 11).

Fig. 11 


\section{RESULTS}

\subsection{Bathymetry:}

The detailed bathymetry of these marginal highs A, B, C, D and E (Fig. 3, Table.1) shows that they form a discontinuous chain in the mid to outer slopes between $15^{\circ} \mathrm{N}$ and $12^{\circ} 40^{\prime} \mathrm{N}$ offshore from the Marmugao and Kochi coasts with mostly NNW--SSE to N--S trend parallel to the west coast and the shelf edge. These are flat topped and lie typically between $245 \mathrm{~m}$ and $860 \mathrm{~m}$ water and each individual high covers an area of about 15 to $570 \mathrm{~km}^{2}$. They are interspersed by bathymetric lows of large relief in the north for example between $C, B$ and A.whereas the high $E$ in the south is far from the highs of the north. The relatively low elevations in the east happen to be due to damming of the terrigenous sediments transported from the coast. The sea floor of the shelf margin basin in the west is relatively smooth except at about $30 \mathrm{~km}$ to the west of the highs where discontinuous isolated bathymetric highs of lesser width (15 to $20 \mathrm{~km})$ and relief $(-100 \mathrm{~m})$ are discretely placed. Their positive reliefs with evenly dipping flanks on either side suggest anticline structures and are more clearly seen in seismic images.

\subsection{Magnetics:}

The shelf margin sedimentary basin is associated with a smooth gradient magnetic low (Figs. 4 - 6; locations in Figs.3). The highs A, C, D and E (but not B) show very subdued magnetic anomalies (Table 1). On profile B1-B1' (Fig. 6) south of the high 'B ' 150-250 nT anomaly is superposed by a low, $10 \mathrm{~km}$ wide with a magnetic field of $\sim 50 \mathrm{nT}$ whereas on profile B-B' (Fig. 5) in the north it is marked by a $<140$ $\mathrm{nT}$ anomaly. The basement highs constituting the Prathap Ridge in the shelf margin basin lying 25 to $30 \mathrm{~km}$ to the west of the bathymetric highs, show consistently significant positive amplitude anomalies of several hundreds nanno-Tesla. Thus the flat topped bathymetric highs A and B, (Figs. 4 and 5 , Table.1) despite their large dimensions seem to be associated with subdued magnetic signatures. This in turn points out that non-magnetic source rocks might be present beneath the highs. Such discrepancies in anomaly amplitudes associated with basement high in the south of the study area have been also reported earlier by Gopala Rao et al. (1987).

\subsection{Gravity:}

The highs A, B and E (profiles A-A', B1-B1' and F-F'; Figs. 4 a, b and d; Table 1) have supposedly owing to their positive seafloor relief's are reflected in positive amplitude free-air gravity anomalies. The basement rises or anticline type structures of $\sim 20 \mathrm{~km}$ width constituting the Prathap Ridge are also associated with significant, up to $80 \mathrm{mGal}$, positive anomalies despite their deep depths, thick sediment 
cover and relatively smaller dimensions. Such rises south of $16^{\circ} \mathrm{N}$ in the shelf margin basin are also associated with positive gravity anomalies (Gopala Rao et al., 1987). Gravity anomalies associated with highs in the slope region are subdued compared to their dimension and basement rises of shelf margin basin. The bathymetric highs of the slope as well as the

basement rises in their west, and associated positive signatures reflect not only their positive seafloor relief's but internal structure as well, unlike their magnetic anomalies.

\subsection{Satellite Gravity:}

The highs $A$ to $E$ are well recognized from NW-SE trending gravity highs forming a chain parallel to the shelf edge. On their seaward side (especially between $14^{\circ}$ and $8^{\circ} \mathrm{N}$ ), clusters of high amplitude closures form numerous chains trending NNE--SSW oblique to the near N--S trending Laccadive Ridge associated with not very appreciable gravity anomalies. The anomalies of the Prathap Ridge are discrete circular high amplitude closures parallel to the coast The amplitudes are expressions of physiography of the features but the striking trends are remarkable different from the NW--SE trending mid-slope bathymetric highs. Despite negligible seafloor relief's of the basement rises constituting the Prathap Ridge, that are mostly covered by sediments, the anomalies associated with them are significantly high In contrast the large margin highs (rising high above the sea floor) are associated with comparatively less amplitude anomalies. These appreciable and conspicuous differences in amplitudes and trends of the anomalies of the rises of the west constituting the Prathap Ridge in comparison to the margin highs of the mid-slope region. bring into focus the varied structure and evolution of the important segments of the western Indian continental margins.

\subsection{Reflection Seismics:}

Seismic images of the outer shelf, slope and shelf margin basin depicted a steep scarp of the seafloor at the present shelf edge and a steep scarp (Fig. 8) further east beneath thick sediments interpreted as the Miocene paleo- outer shelf edge (Prasada Rao and Srivastava 1981). Their disposition clearly marks faulting of the present as well as the paleo-shelf edge. They are covered by thick $\sim 3 \mathrm{~s}$ (TWT) near parallel layered sediment sequences (Figs 4, 5, 8 and 9). Further, the sediment sequences either terminate against steeply dipping flanks or drape over the highs (Fig. 7). The farthest highs, $G$ in the south (Fig. 8) and $\mathrm{H}$ in the north (Fig. 9) are sub-surface and overlain by 1.5 to $2.0 \mathrm{~s}$ thick (TWT) semitransparent to transparent layered sediments. The high structure $G$ in the south consists of a western steeply dipping flank, and gently dipping eastern flank of step-like structures down-faulted to the east bounded by series of parallel faults. The offsets in seismic reflectors of the high structure $\mathrm{H}$ in the north 
mark near vertical faults in the east and adjoining sediment filled graben reflect extension, rifting and subsidence. The lower half of their flanks, especially of highs A, B and E are covered by mostly slumped sediments 70-100 m thick (Figs. 4, 5 and 7) and the eastern flanks are juxtaposed with local sedimentary basins. A series of offsets of seismic reflectors along the flanks marks near vertical parallel faults resulting in step-like structures (Figs. 6 to 9). To the west of the highs, basement topography pierces through the sediments surface at the seafloor. The basement rises are isolated, localized and narrow positive seafloor relief features with gentle and evenly deepening flanks forming a chain. They are more clearly depicted in 1) inverted ' $V$ ' shapes associated with hyperbolic reflections with vertices upward and resembling anticline structures. and 2) the positive relief on the seafloor in the north. The one on profile H-H' (Fig. 9) is carpeted by sediments and composed of double peaked inverted ' $\mathrm{V}$ ' shaped structures at shallow depth separated by thick, $0.1 \mathrm{~s}$ (TWT) sediments-filled depression of $\sim 0.2$ $\mathrm{km}$ wide. Over all the seafloor relief's shows a broad anticline with gentle and evenly deepening flanks on either side overlain by $\sim 2 \mathrm{~s}$ (TWT) thick sediments. The seismic reflectors of relatively wide structure E (Fig. 7) show a series of offsets, and down throw of 0.2-0.3 s (TWT) along both flanks and suggest parallel faulting on either side of the structure extending to the basement. Offsets of the seismic reflectors of the highs at greater depths mark deep-seated faults associated with extensional tectonics. The high in the south, 'G' (Fig. 8) shows faults extending to basal reflectors. They are present at several places suggesting faults extending to the basement, down thrown and tilting to the east. It is in contrast to other highs of the slope region and implies a faulted block under sediment loads and extensional tectonics. A sedimentary basin, $\sim 30 \mathrm{~km}$ wide with $\sim 2 \mathrm{~s}$ (TWT) thick sediments, appears between the margin highs of the mid-slope and the basement rises of the shelf margin basin. The flat topped highs of the slope region separated from the sedimentary basin basement rises totally differ in structure, morphology and the small inverted $V$ shaped basement rises. Acoustic masks within sediments occur between 0.4 and $0.5 \mathrm{~s}$ (TWT) at two locations (Fig. 8) which become more intense to the west.

\subsection{Seismic Refraction:}

Seismic refraction results show a multilayered crustal velocity structure with P-wave velocities of 1.6$2.0 \mathrm{~km} / \mathrm{s}, 3.2-4.4 \mathrm{~km} / \mathrm{s}, 5.5-5.7 \mathrm{~km} / \mathrm{s}, 6.3-6.4 \mathrm{~km} / \mathrm{s}$ and $7.2-7.3 \mathrm{~km} / \mathrm{s}$ is adjoining the study area. In the adjoining continent a layered crust with velocities $5.68-6.5 \mathrm{~km} / \mathrm{s}, 7.15 \mathrm{~km} / \mathrm{s}$ and $8.13 \mathrm{~km} / \mathrm{s}$ has been reported (Fig.10 a and b).The 6.3-6.4 km/s velocity is equivalent to upper crustal layer on land comprising granites and granitic gneisses. Similarly the $7.2-7.3 \mathrm{~km} / \mathrm{s}$ velocity is akin to lower crustal velocities. Velocities of $4.7-4.9 \mathrm{~km} / \mathrm{s}$, typical for volcanic trap rocks and velocity approximately 8.0 $\mathrm{km} / \mathrm{s}\left(P_{n}\right)$ from Moho boundary, found in the trap covered Deccan Syneclise of India (Kaila et al.1981 a 
and b) are not seen in the study area. Krishna et al. (2006) have reported seismic images of intrusions (sills and dykes) within the sediments extruded volcanics and stretched continental crust in the Laxmi Basin off the Mumbai coast to the north of the study area. They also attributed 6.2-6.3 km/s and 3.2-4.4 $\mathrm{km} / \mathrm{s}$ velocity layers of the basin to the granites and sediments intruded by volcanic formations respectively. Thus the above 3.2-4.4 km/s and 5.5-6.4 km/s and 7.2-7.3 km/s velocities in the study area could be interpreted due to sediments with intrusive volcanic/ volcano-clastics, schists and lower crustal rocks. It is an accepted fact that volcanics occur beneath Teritiary sediments in the offshore area, west of India due to the Reunion hot-spot activity when Indian plate slid over the trail of the hotspot. The volcanics overlying granites are probably thin in the offshore especially in the south and may not be within detectable limits of the refraction measurements. The velocities and crustal structure in the study area, thus, probably imply basaltic volcanic over granites.

Therefore, the magnetic and gravity anomalies could be explained with two possible crustal models of sediments, 1) thick volcanics over the non-magnetic rocks or sediments and, 2) thin volcanics over the non-magnetic rocks. The geology of adjoining onshore and regional tectonics of the margin support the latter model. The anomalies account for $\sim 23 \mathrm{~km}$ thick crust consisting of thin (up to $1.8 \mathrm{~km}$ ) volcanic rocks of 3 to $6 \mathrm{~A} / \mathrm{m}$ magnetization under-lain by thick (up to $18 \mathrm{~km}$ ) basement rocks of $2.62-2.92$ $\mathrm{gm} / \mathrm{cc}$ density, followed by dense mantle material of $3.2 \mathrm{gm} / \mathrm{cc}$ density with volcanic and dyke like structures (Fig. 11). A schematic presentation is made in Figures 8A \& B to depict the two stages of development of the highs and their formation.

Figures 12 A \& B

In developing this schematic representation information from the seismic reflectors configurations, morphology of the margin highs, the basin basement rises and associated deep-seated faults bounding the structures, down throws, onshore geology and regional tectonics (especially the offshore extents of the onshore faults) have been utilised.

\section{Discussion:}

\subsection{Structure}

The seismic images of highs in the slope region reveal very steep western flanks and gentle dipping eastern flanks associated with series of faults extending to basal ref- lectors. This pattern suggests that the slopes are subsided faulted blocks, probably separated from continent. In the process some of them, especially the subsurface high ' $\mathrm{H}$ ' appears tilted to the east perhaps due to the compressive 
forces of the sea floor spreading from the west in the eastern Arabian Sea. The free-air gravity anomalies of the highs are elongated NW-SE or N-S, while the anomalies due to the basement rises constituting the Prathap Ridge trend NE-SW, forming a chain oblique to the shelf edge especially adjoining the highs $A, B, C$ and $D$. They are, thus, nearly transverse to the NNW-SSE trending bathymetric highs of the mid-slope region and differ in amplitudes, shapes and trends from the highs. Most of the mid-slope highs are associated with negligible or subdued magnetic anomalies compared to their dimensions and could be explained with very weak magnetic granitic crust overlain by thin volcanic rocks and sediments. The lateral variations in the observed anomalies across the high $\mathrm{B}$ and significant anomalies of the deep-sea basement rise point to subdued amplitudes associated with the highs in comparison. Such lateral variations in anomaly amplitudes could occur due to varied thickness of volcanic piles that were intruded into the weak zones along flanks of non-magnetic rocks, granites. This is clearly noted from seismic images on profile H-H' (Fig. 9). The model parameters of crustal structure consisting of thin basalts, intrusions and extrusions of varied thickness and the non-magnetic basement rocks suggest the presence of continental crust. The chain of flat topped margin highs and sub-surface highs noted in the north as well as in south with the typical morphological characters are geographically distant and lie almost $25-30 \mathrm{~km}$ east of the Prathap Ridge and separated by $\sim 30 \mathrm{~km}$ wide sediment filled basin. The ridge comprises of isolated basement rises. Present modeled thickness of $>18 \mathrm{~km}$ crust of the highs consisting of sediments (3.2- $4.4 \mathrm{~km} / \mathrm{s}$ velocities) and granites (5.5-6.4 $\mathrm{km} / \mathrm{s}$ velocities) is akin to the upper crust of south India (6.2-6.3 km/s velocities). Therefore the study area seems to have a crust consisting of thin volcanics with granitic basement. Earlier studies have indicated that 1) continental crust consisting of granitic and volcanic rocks of the Seychelles microcontinent in the western Arabian sea got separated from Indian plate (Davey and Stephen, 1991), 2) Presence of volcanic rocks overlain by upper Paleogene and Neogene Tertiary sediments (Murthy et al.,1999), 3) Cenozoic sediments and thin basalts are underlain by thick Pre-cambrian granitic rocks of Bombay High region at outer shelf of Mumbai coast (Gopala Rao, 1990), and 4) stretched continental granitic crust intruded by volcanic rocks in the Laxmi Basin (Krishna et al., 2006). In view of the above, the presence of a crust consisting of sediments, volcanics and granitic rocks in the western continental margin (wherein the volcanics are intruded and extruded by Reunion hot-spot magmatism during northward drift of the Indian plate) is more plausible. The modeled crust parameters of the highs, their geographical location and geomorphic and geophysical expression, velocity structure, regional tectonics and geology of the shelf, slope and shelf margin basin lend support to the presence of nonmagnetic and low density crust of the highs. The large 'terrace' in the mid-slope region of the Trivandrum coast $\left(\sim 8^{\circ} \mathrm{N}\right)$ consists of continental crust (Yatheesh et al., 2006) further supports that midslope flat topped highs in the study area are continental in nature. 


\subsection{Origin}

Previous studies have identified the presence of prominent fault controlled NNW-SSE trending basement anticlines in the slope region of the Mumbai coast of India (Harbison and Bassinger, 1973) .They are part of 'Kori- Comorin Ridge' (Biswas and Singh, 1988). But the basement rise structures seismically imaged and also noted from the geophysical signatures have been inferred as part of Prathap Ridge (in 1400-2000 m water depth) parallel to southwest coast of India (Krishna et al., 1994). If the margin highs are igneous, akin to the Prathap Ridge, they should depict similar seismic reflection pattern at shallow depth. On the contrary, the parallel reflectors that terminate against flanks of the highs suggest a 'horst' structure that is bounded on both sides by steep faults. Sediments thickness patterns and faulted basement are confirmed from the fault-bounded trough, named the 'Kori-Comorin Depression' (Biswas, 1989) or "eastern part of shelf margin basin" (Gopala Rao et al., 1987). As such, the flat topped highs and the buried basement highs represent fault controlled horst and graben structures of the mid-slope region. The crustal velocity structure in the area (Fig. 10) is similar to the structure noticed in the adjacent main-land as well as in the offshore Laxmi Basin.The gravity and magnetic anomalies associated with the highs differ in shape and amplitude from the rises as seen especially in the satellite gravity anomalies. The highs in the mid-slope region(in 245 to $860 \mathrm{~m}$ water), the 'terrace' (in $2000 \mathrm{~m}$ water) to the east of the Comorin Ridge, (in $2000 \mathrm{~m}$ water , $78^{\circ} \mathrm{E}$ ) and the Kori-High (in 200-500 m water) in the outer-shelf of the Kachchh coast in the north differ geographically and physiographically from basement rises of the eastern shelf margin basin or Kori-Comorin depression. Even though the northern part of the Comorin Ridge, (south of the southwest coast of India) is continental (Sreejith et al., 2008), northward continuity of the NNW-SSE trending Comorin Ridge up to the highs and then perhaps further north up to the Kori-High and Prathap Ridge structures is unlikely. Such a scenario it is not convincing to suggest that the Comorin Ridge continues to the north connecting the highs and rises.

The modeled crust, tectonics, geographic locations and geophysical signatures of the basement rises of the eastern shelf margin basin and mid-slope flat-topped bathymetric highs indicate that the Prathap Ridge is composed of volcanic rocks in the study area. They are perhaps emplaced during northward drift of India over the hot-spot. The NNE-SSW, E-W, N-S and E-W trending faults of Precambrian age crust are reported at Palghat, Bhavani and Moyar in southwest India (Ramachandran and Rama Rao, 1999). Major EW, N-S and NE-SW faults of the south and southwest coast of India extend into the offshore region (Eremenko and Datta, 1968; Gopala Rao et. al., 1987; Kolla and Coumes, 1990; Subrahmanyam et al., 1993). The onshore E-W faults extend offshore and we propose that 1) the NNW-SSE faults extending offshore sheared the continent resulting in crustal slivers in the offshore 
parallel to the shelf edge and the west coast, 2) They cut across the slivers resulting in formation of the 'horst' structures in the slope, and 3) the basement highs and depressions in between the faults form the highs and sediment filled depressions or grabens. Seismic images of such faulted and subsided continental blocks and basement highs, $\mathrm{H}$ and $\mathrm{G}$ beneath thick sediments, identified along the slope both in the north (Fig. 9) and south (Fig. 8) strongly support down faulting of the basement. A schematic illustration and the structural interpretation of the faults, and the disposition of fault patterns are depicted in Figures (12 A and B).

We opine that formation of NNW-SSE trending faults was an earlier event and the ENE-WSW trending faults formed later resulting in faulted crustal blocks forming the discontinuous chain of the NNW-SSE trending marginal highs. The younger ENE-WSW trending faults are also perhaps responsible for the slight lateral displacement from their main NNW-SSE structures.

\subsection{Subsidence}

The margin highs are unique with flat tops lying at $\sim 350 \mathrm{~m}$ water. The reasons for such flat tops could be sub-aerial exposure and weathering in the past. The present depth of these marginal highs is due to block subsidence by about $400 \mathrm{~m}$ with respect to the present sea level and rifting during Paleogene. Sea level regression during the Late Oligocene ( $29 \mathrm{Ma})$ and erosion of the pre-existing mid-shelf sediments was reported off Mumbai and Marmugao coasts (Mohan, 1985; Chaubey et al., 2002). Subsidence of about 200 to $400 \mathrm{~m}$ and erosion during the Miocene (Mohan, 1985; Rea, 1992; Whiting et al., 1994) followed by uplift of shelf edge off Mumbai coast (Mohan, 1985) by about 100-150 m during the past 3.5 Ma was reported. Based on this evidence the following subsidence process of the highs is suggested: Sub-aerial plaination during Late Oligocene and subsidence by $\sim 450 \mathrm{~m}$, during lower Middle - Upper Miocene and reaching the present depth during last 3.5 Ma as a result of uplift of 100-150 m.

The Wallaby, Exmouth and Whombhat Plateaus of the north-west coast of Australia (Gaina et al., 2003) and the southern Keruguelen Plateau / Elan Bank of the Central Indian Ocean (Weis, et al., 2001) are micro-continents rifted from the main-lands in a unique setting and interaction of the mantle plume with the continent. We suggest fault controlled extensional tectonics played major role for formation of the highs in the study area as in the above case. The tectonic process detached continental fragments due to faulting in the first stage (Fig. 12A) and dissected by transverse fault system in the next stage (Fig.12 B). Further subsidence of these rifted blocks in between the highs resulted in the formation of sediment filled basins or grabens and associated subsided basement highs of the shelf margin in the west. 


\subsection{Continental crust of the bathymetric highs, mid-slope region of western continental margin of India.}

Thus the margin-parallel bathymetric highs that developed signify the importance of the tectonic process which was also well documented in the case of separation of Madagascar, Seychelles, and Laxmi Ridge from the Indian shield. The flat top surfaces of these marginal highs up to $570 \mathrm{~km}^{2}$ area each occur at almost similar water depths of $245-860 \mathrm{~m}$. This suggests probably that all the highs have formed due to similar or same tectonic process and have been peri-plained simultaneously. The midslope flat topped bathymetric highs are fault controlled continental slivers consisting of Tertiary clastics and carbonates sediments, thin volcanics rocks and thick granitic crust. The basement rises to the west of the highs are igneous intrusions emplaced by the Reunion plume trail into the crust along weak zones or faults. So we propose initial rifting in NNW direction and separation of a continental sliver from the main land and later cut across by the E-W to ENE-WSW faults Volcanics rocks were emplaced along NE trending weak zones, which are presently seen as basement rises to the west of the bathymetric highs. The sediment-covered highs in the slope region (Figs. 8 and 9) thus mark the rifted and subsided crustal fragments Thus the highs form an integral part of the horst- graben structure on the west coast.

\section{Conclusions}

1. The flat topped bathymetric highs in the slope region and basement rises constituting the Prathap Ridge are not genetically related.

2. The studies suggest that the Prathap Ridge complex is volcanic construct emplaced on to the northward moving Indian Plate after the main phase of Deccan volcanism by Reunion hotspot and formed during its trail.

3. The chain of parallel discretely placed margin highs at almost similar water depths in the mid slope region are continental slivers and horst structures, part of the Indian continent that broke away from the continental margin during stretching and faulting. These highs stand out as horsts caused by the intersection of major NNW-SSE and ENE-WSW faults. North-south rifting of the crust intersected by the ENE-WSW or NE-SW faults, sub-aerial erosion and plaination of tops of rifted segments and thermo-mechanical subsidence contributed to the margin parallel flat topped highs. Thus the highs in the slope region of the west coast of India have attained almost equal depths.

4. Based on the geographic distribution, crustal structure and physiography of the various structural 
features it would be difficult to propose any linkage in an unequivocal manner between Comorin Ridge, Prathap Ridge and the shelf/slope (margin) highs.

\section{Acknowledgments}

We are grateful to the Director, NIO for his constant encouragement. Thanks are also due to all the participants of ORV Sagar Kanya Cruises SK 114, SK 65, and SK 158. Part of this study was carried out as surveys for LOICZ Project (under MLP0003) undertaken at NIO for which the support from DOD is acknowledged. DST New Delhi has also provided financial grant for carrying out the work. Financial support was provided to D. Gopala Rao through the CSIR Emeritus Scientist scheme. The excellent cooperation by ship's Masters and their crew during all these cruises is highly acknowledged. We are thankful to Mr. Pramod Pawaskar and Mr. Shaikh Ali Karim for preparations of illustrations. This is NIO's contribution No.

\section{References}

Biswas, S.K., 1988. Structure of the western continental margin of India and related igneous activity. Memoir Geological Survey of India 10, 371-390.

Biswas, S.K.,1989. Hydrocarbon exploration in Western offshore basins of India. Geological Survey of India Special Publication 24, 185-194.

Biswas, S.K., 2008. Comments on "Estimates of effective elastic thickness along the southwest continental margin of India using coherence analysis of gravity and bathymetric data-Geodynamic implication by Shenna V, Dev., Radhakrishna, M., Subrahmanyam, C., Journal Geological Society of India 2007. 70(3), 475-487". Journal of Geological Society of India 71, 593-595.

Biswas, S.K., Singh, N.K., 1988. Western continental margin of India and hydrocarbon potential of deep-sea basins. 7th Offshore South East Asia Conference, Singapore. 170-181.

Chaubey, A.K., Gopala Rao, D., Srinivas, K., Ramprasad,T.,Ramana, M.V., Subrahmanyam, V., 2002. Analyses of multichannel seismic reflection, gravity and magnetic data along a regional profile across the central-western continental margin of India. Marine Geology 182, 303-323.

Chakraborthy, B., Mukhopadhaya, R., Jauhari, P., Mahale, V., Shashikumar, K. Rajesh, M., 2006. Fine - scale analysis of shelf-slope physiography across the western continental margin of India, GeoMarine Letters 26, 114-119.

Devey, C.W., Stephens, W.E., 1991. Tholeiitic dykes in the Seychelles and original spatial extent of the Deccan. Journal of Geological Society of London 148, 979-983.

Eremenko, N.A., Datta, A.K., 1968. Regional geological framework and evaluation of the petroleum prospects of the Laccadive archipelago and the adjoining offshore territory, southwest India. Bulletin Oil and Natural Gas Commission of India 5, 29-40. 
Gaina, C., Muller, R.D., Brown, B., Ishihara, T., 2003. Micro-continent formation around Australia. In: Hillis, R., Muller R.D. (Eds.), The Evolution and Dynamics of the Australian Plate. Joint Geological Societies of Australia \& America Special Paper 22, pp.399 - 410.

Gopala Rao, D., Bhattacharya, G.C., Subba Raju, L.V., Ramana, M.V., Subrahmanyam, V., Raju, K.A.K., Ram Prasad, T., Chaubey, A.K., 1987. Regional marine geophysical studies of the south western continental margin of India. In: Rao, T.S.S., Natarajan, R., Desai B.N., Swamy G.N., Bhat S.R. (Eds.), Contributions in Marine Sciences. Dr. S.Z. Qasim Sastyabdapurti Felicitation volume. National Institute of Oceanography, pp. 427-437.

Gopala Rao. D., 1990. Magnetic studies of basement off Bombay Coast, West of India. Tectonophysics 174, 2665-2682.

Harbison, R.N., Bassinger, B.G., 1973. Marine geophysical study off western India. Journal of Geophysical Research 78, 432-440.

Kaila, K. L., Roy Chowdhury., Reddy, P.R., Krishna, P.R., Hari Narayan. T, Subbotin, S.I., Sollogub, V.B., Chekuno, A.V., Kharetchko, G.E., Lazarenko, M.A., Ilchenko, T.V., 1979. Crustal structure along Kavali-Udipi profile in the Indian Peninsular shield from deep seismic sounding. Journal of Geological Society of India 20, 307-333.

Kaila K.L., Reddy, P.R., Dixit M.M., Lazarenko, M.A., 1981a. Deep crustal structure at Koyna, Maharashtra, indicated by deep seismic soundings. Journal of Geological Society of India 22, 1-16.

Kaila K.L., Murty, P.R.K., Rao, B.K., Kharetchko, G.E., 1981b. Crustal structure from deep seismic soundings along the Koyna II (Kelsi-Loni) profile in the Deccan Trap area, India. Tectonophysics 73, 365-384.

Kolla, V., Coumes, F., 1990. Extension of structural and tectonic trends from the Indian subcontinent into Eastern Arabian Sea. Marine and Petroleum Geology 7,188-196.

Krishna, K.S., Murty, G.P.S., Gopala Rao, D., 1994. Identification and origin of a subsurface ridge on the continental margin of western India. Marine Geology 118, 283-290.

Krishna, K.S., Gopala Rao, D., Sar. D., 2006. Nature of the crust in the Laxmi Basin $\left(14^{\circ}-20^{\circ} \mathrm{N}\right)$, western continental margin of India. Tectonics 25:TC1006, doi:10.1029/2004TC001747.

Mohan, M.,1985. Geohistory analysis of Bombay High region. Marine and Petroleum Geology 2, 350360.

Murthy A.V.S., Arasu R.R., Dhanawat B.S., Subramanyam V.S.R., 1999. Some aspects of deep water exploration in the light of new evidences in the western Indian offshore. In: Bhatnagar A.K., (Ed.), Proceedings of Third International Petroleum Conference \& Exhibition, pp. 457-460.

Naini, B.R. (1980) A geological and geophysical study of the continental margin of western India, and the adjoining Arabian Sea including the Indus Cone. Unpublished Ph. D. Thesis, Columbia University, New York. pp. 1-167.

Naini, B.R., Talwani, M., 1982. Structural framework and the evolutionary history of the continental margin of western India. In: Watkins J.S., Drake, C.L. (Eds.), Studies in Continental Margin Geology. American Association of Petroleum Geology Memoir 34, 167-191 
Prasada Rao, R ., Srivastava, D. C., 1981.Seismic stratigraphy of west Indian offshore. Proceedings of the work-shop on Geological Interpretation of Geophysical Data, KDMIPE publication. pp. 49-57

Rao, B.R., Veerayya, M., 2000. Influence of marginal highs on the accumulation of organic carbon along the continental slope off western India. Deep-Sea Research II47, 303-327.

Rea, D.K., 1992. Delivery of Himalayan sediment to the northern Indian Ocean and its relation to global climate, sea level, uplift and seawater strontium. In: Duncan, R.A., et al. (Eds.), Synthesis of results from scientific drilling in the Indian Ocean, Geophysical Monograph, American Geophysical Union 70, 387-402.

Ramachandran, T.V., Rama Rao, K.L.V., 1999. Major and trace element Chemistry of Charnokites and gneisses in the granitic belt of south India. In: Murthy, N.G.K., Rama Mohan, V., (Eds.), Proceedings of the International symposium on granulite facies rocks, Chennai, India. Special publication No.4, Geologists Association of Tamil Nadu, Chennai, India. pp. 351-367.

Sandwell, D.T, Smith, W.H.F.,1997. Marine gravity anomaly from Geosat and ERS1 satellite altimetry. Journal of Geophysical Research 102, 10039-10054.

Sreejith, K.M., Krishna, K.S., Bansal, A.R., 2008. Structure and isostatic compensation of the Comorin Ridge, north central Indian Ocean. Geophysical Journal International 175, 729-741.

Subrahmanyam, V., 1987. Offshore extension of the structural element of Udipi, confirmation from marine magnetics. Journal of Geological Society of India 29, 256-263.

Subrahmanyam, V., Ramana, M.V., Gopala Rao, D., 1993. Reactivation of Precambrian faults on the southwestern continental margin of India, evidence from gravity anomalies. Tectonophysics 219, 327339.

Weis, D., Ingle, S., Damasceno, D., Frey, F.A., Nicolaysen, K., Barling, J., 2001. Origin of continental components in Indian Ocean basalts: evidence from Elan Bank (Keruguelen Plateau- ODP Leg 183, Site 1137). Geology 29, 147-150.

Whiting, B.M., Karner, G.D., Driscoll, N.W., 1994. Flexural and stratigraphic development of the West Indian continental margin. Journal of Geophysical Research 99, 13791-13811.

Yatheesh, V., Bhattacharya, G.C., Mahender, K., 2006. The terrace like feature in the mid-continental slope region off Trivandrum and a plausible model for India-Madgascar juxtaposition in immediate predrift scenario. Gondwana Reserch 10, 179-185. 


\section{Figures:}

Fig.1 Satellite derived bathymetric map of the western margin of India. Bathymetry at varied (100 to $1000 \mathrm{~m}$ ) contour interval. Triangles, closed circles and thick continuous lines are Sono-buoy refraction stations, seamounts, and inferred Kori-Comorin Ridge by Biswas, S,K. (2008) respectively.

Fig. 2. Satellite derived free-air gravity map at contour interval $20 \mathrm{mGal}$ is prepared from 1"x1" interval data base of Sandwell and Smith (1997). The gravity highs associated with the bathymetric high structures A, B, C, D and E are marked. Closed contours mark localized physiographic highs and lows reflect Prathap Ridge and Laccadive Ridge structure. Dashed lines mark chains of gravity highs formed due to volcanic emplacements.

Fig. 3 Swath bathymetry depth contour map depicts the mid-slope/margin highs $A, B, C, D$ and $E$ (contour interval $200 \mathrm{~m}$ ). A-A', B-B', B1-B1', F-F', G-G' and H-H' are profiles of geophysical investigations. A to $\mathrm{E}$ denote identified margin highs. KKDW-17-Oil Industry drill well.

Fig. 4. Single channel seismic reflection images, and associated gravity and magnetic anomalies along profile A-A' showing morphology of the slope, bathymetry high and surface and sub-surface structure along entire length of profile (Modified after Chaubey et al., 2002). Profile location is shown in Fig.3.

Fig. 5 Single channel seismic images along the profile B-B' showing morphology of the slope and margin high B along with magnetic anomalies (Modified after Rao and Veerayya, 2000). Profile location is shown in Fig.3.

Fig. 6 Multi-channel seismic images along the profile B1-B1' showing morphology of the shelf, slope margin high 'B', Prathap Ridge and associated free-air gravity and magnetic anomalies. Profile location is shown in Fig.3.

Fig. 7 Multi-channel seismic images along the profile F-F' showing margin high E, Prathap Ridge associated free-air gravity anomalies. Vertical and horizontal lines are faults and seismic sequences boundaries respectively.

Fig. 8 Multi-channel seismic images (CDP gather) along the profile G-G' showing present shelf edge, buried Miocene shelf break, subsided and faulted block G (margin high), and buried Prathap Ridge. Vertical dashed lines are faults.

Fig. 9 Multi-channel seismic images (CDP gather) along the profile $\mathrm{H}-\mathrm{H}$ ' showing present and Miocene 
shelf edges, subsided margin high $\mathrm{H}$, buried double peaked Prathap Ridge and eastern flank of the Laccadive Ridge. Vertical dashed lines are faults.

Fig. 10. Velocity and depth models are constructed from sono-bouy refraction measurements after Naini (1980) and Naini and Talwani (1983). The onshore Udipi-Kavali crust model data are after Kaila et al., (1979)

Fig. 11. Crustal and density model structure are from 2D model interpreted from free-air gravity and magnetic anomalies (Profile B1-B'). Inverted V shaped vertical columns are volcanic intrusions. SMH is shelf margin high. PR - Prathap Ridge

Fig. 12. Schematic illustration depict the inferred two stages of tectonic settings.

A) Structural pattern parallel to the western continental margin of India and rift process of initial stage.

And B) Depicts fault controlled bathymetric highs. Dashed lines are the identified east-west faults of the western margin of India extending offshore in the study area bi-sected the rifted continental fragment of the mainland.

\section{Tables:}

Table.1. shows locations, physiography, seismic, gravity, magnetic signatures of the shelf margin bathymetric highs.

Table.2. seismic refraction measurements are sono-buoy stations of south-west continental margin of India after Naini (1980) and Naini and Talwani (1982) and Udipi-kavali DSS profile after Kaila et al. (1979). 


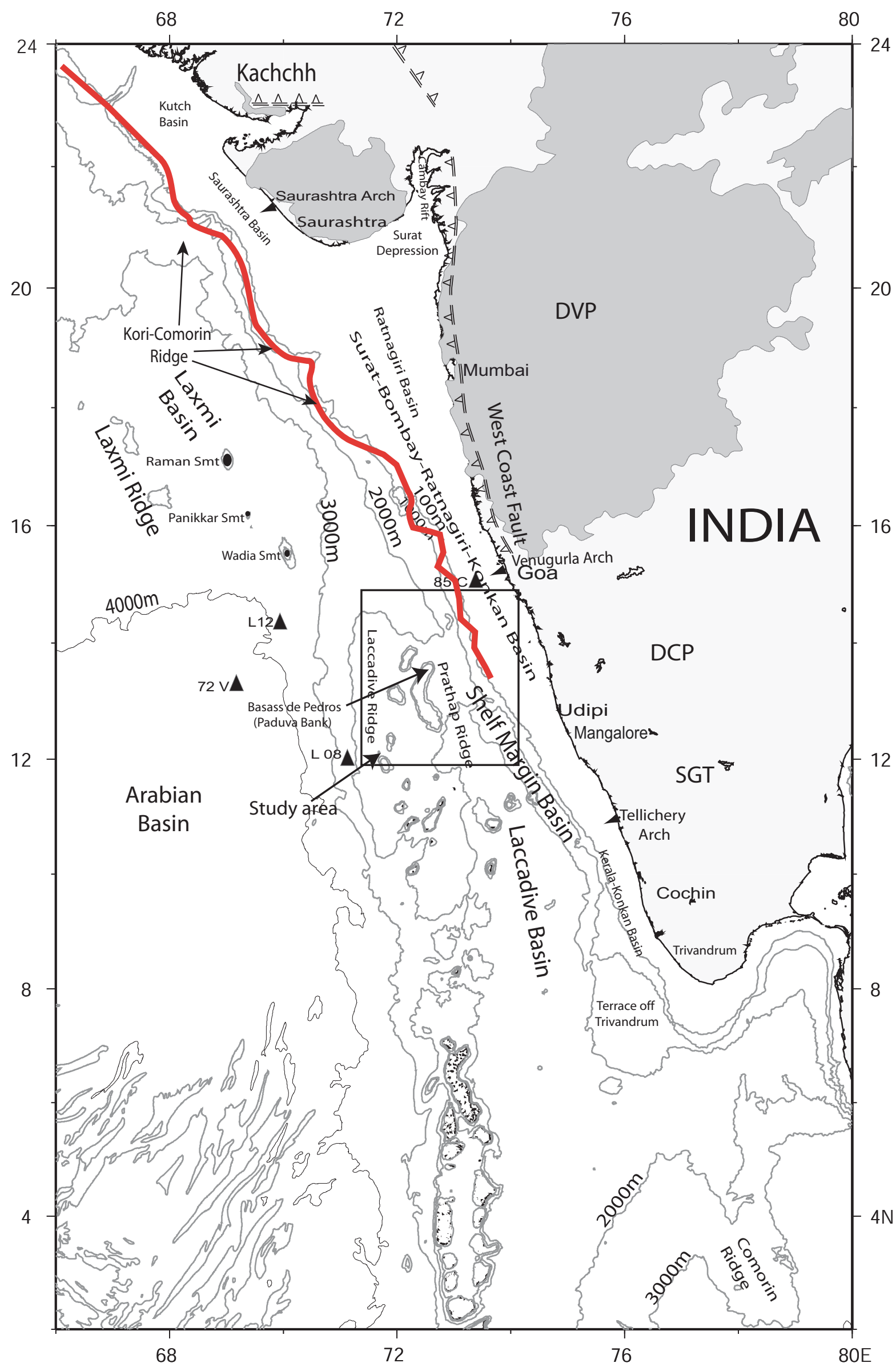

Fig. 1 Gopala Rao et al., 2009 
Figure 2

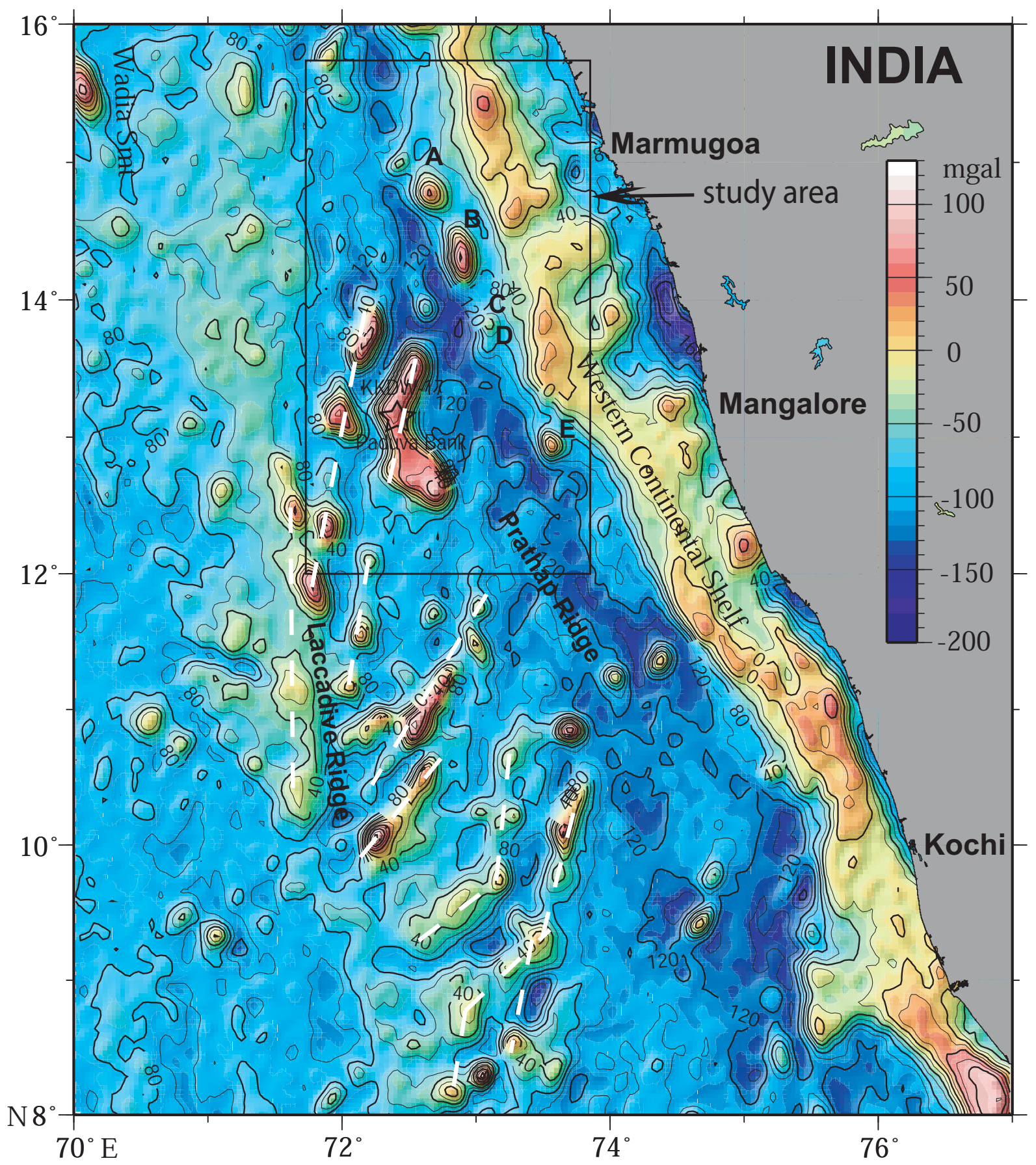

Fig. 2 Gopala Rao et al., 2009 
Figure 3

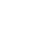

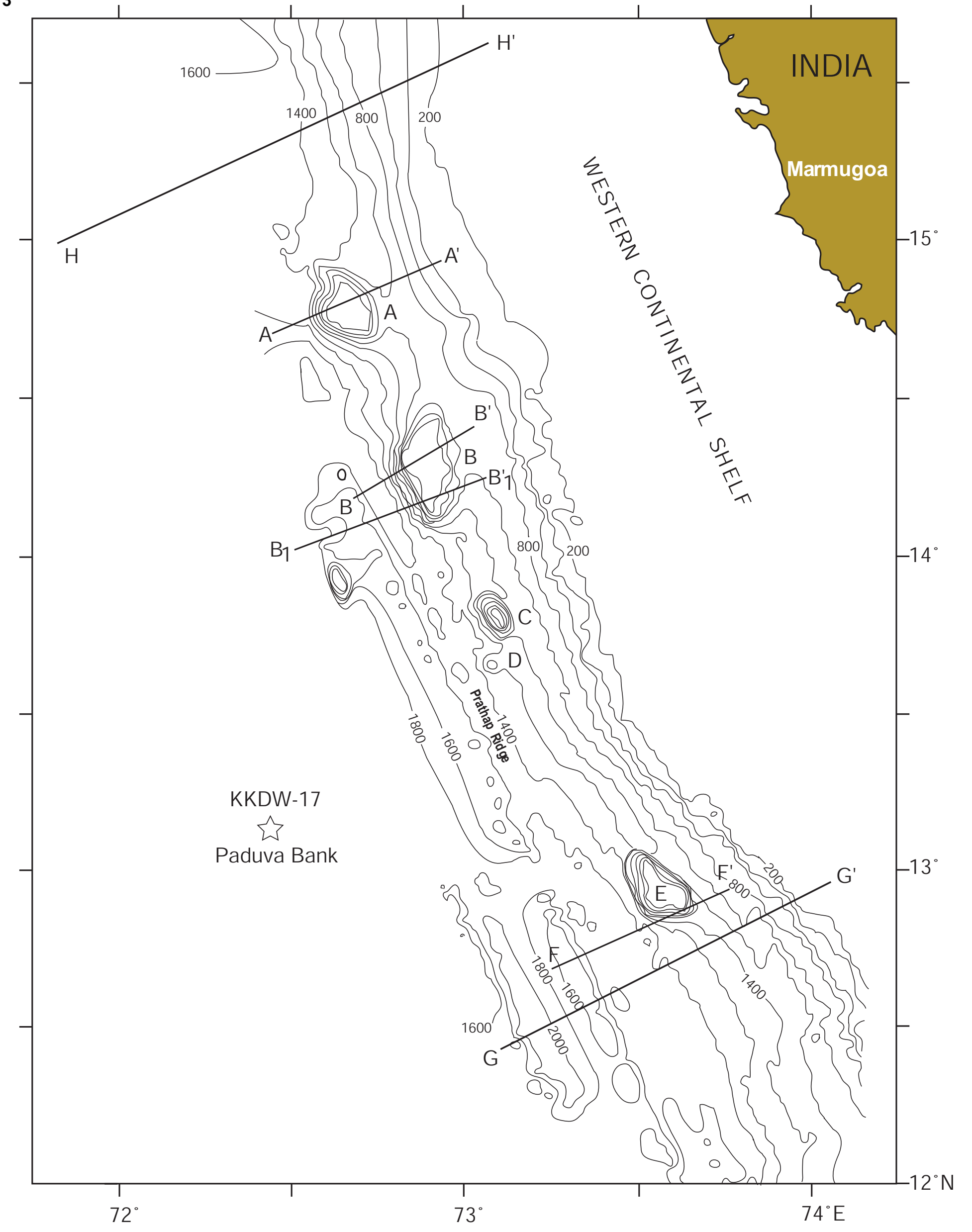

Fi9. 2 Gopala Rao et al., 2009 

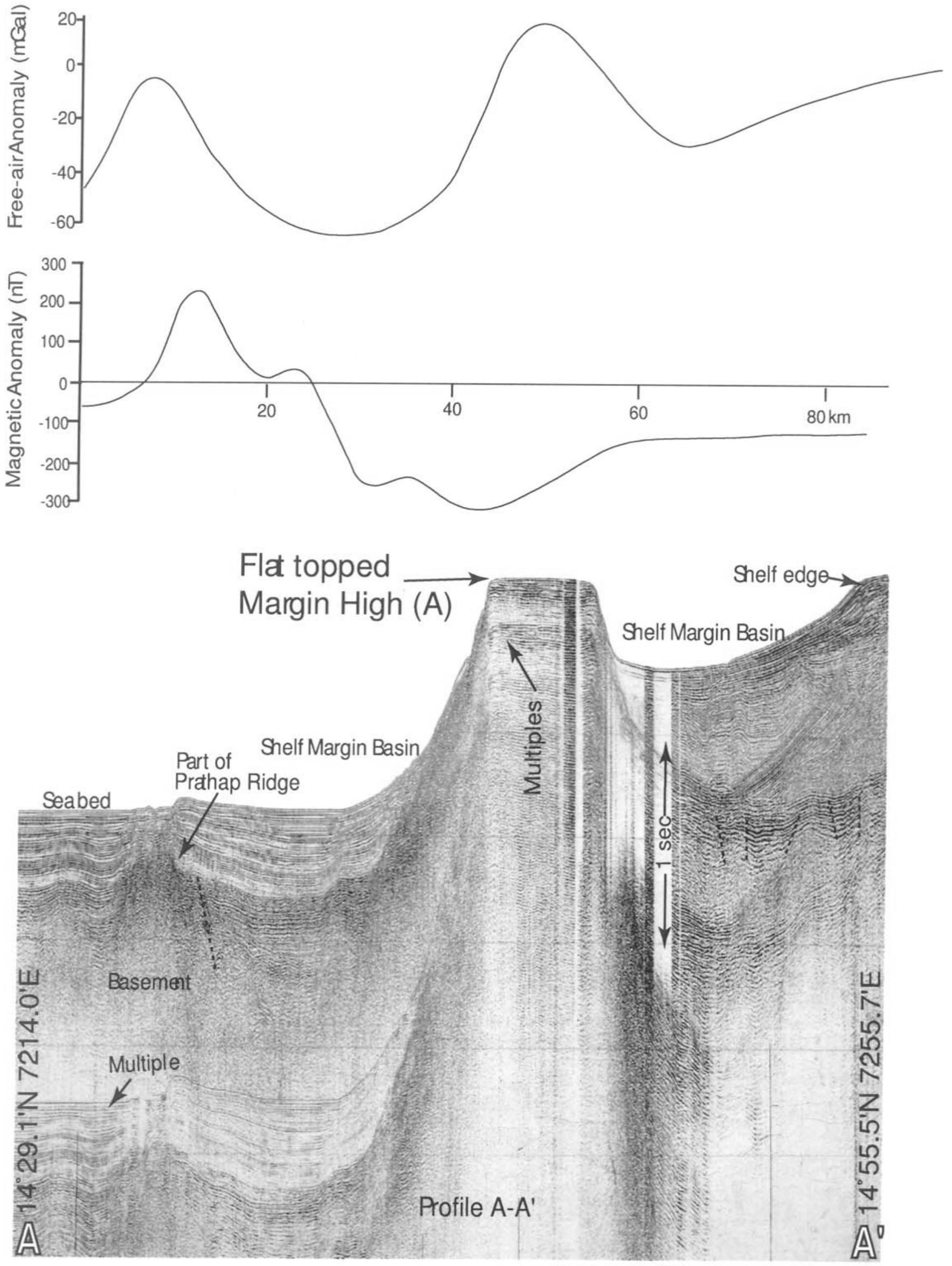

Fig.4 Gopala Rao et al.,2009 
Figure 5
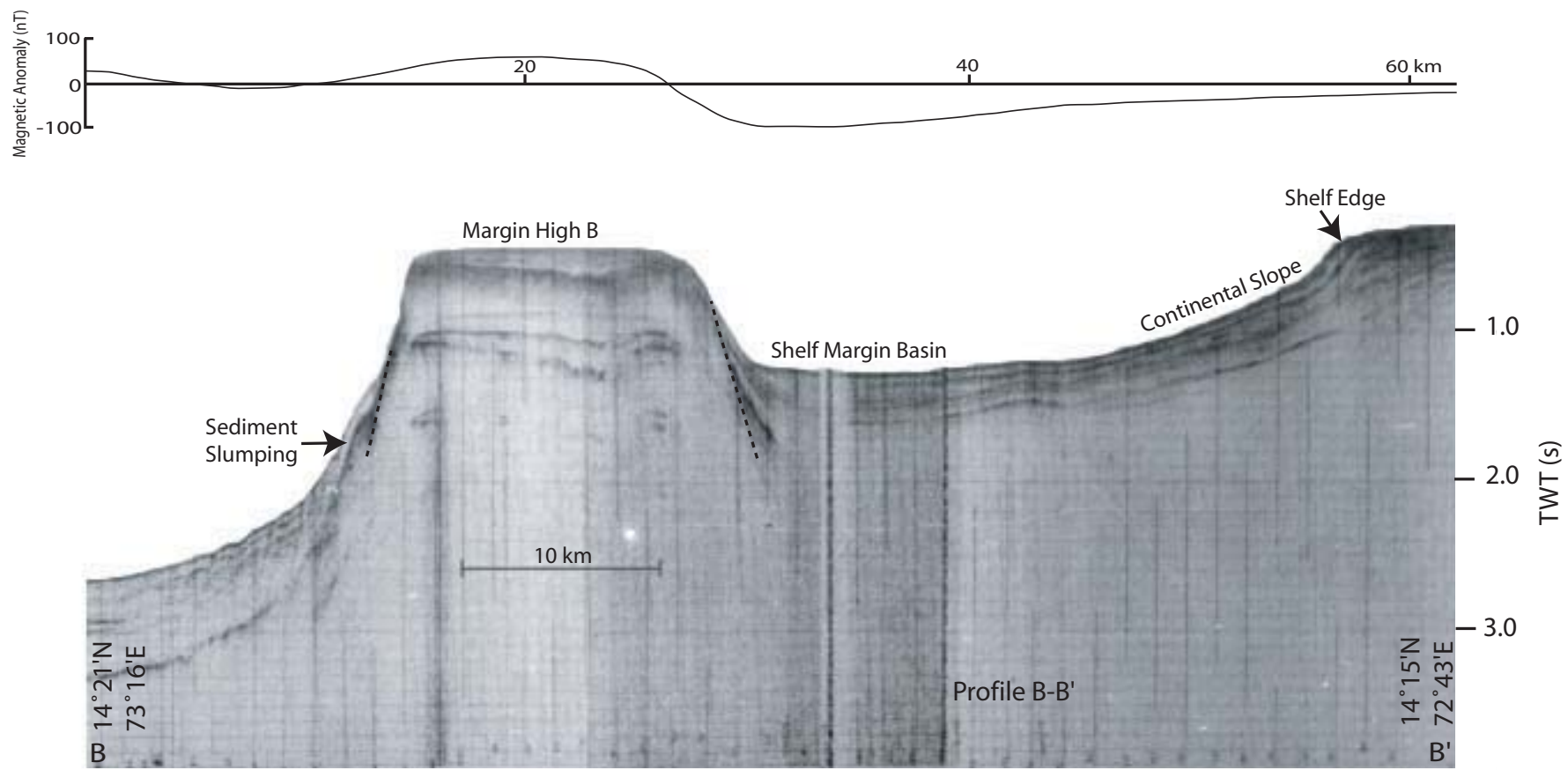

Fig. 5 Gopala Rao et al., 2009 
Figure 6

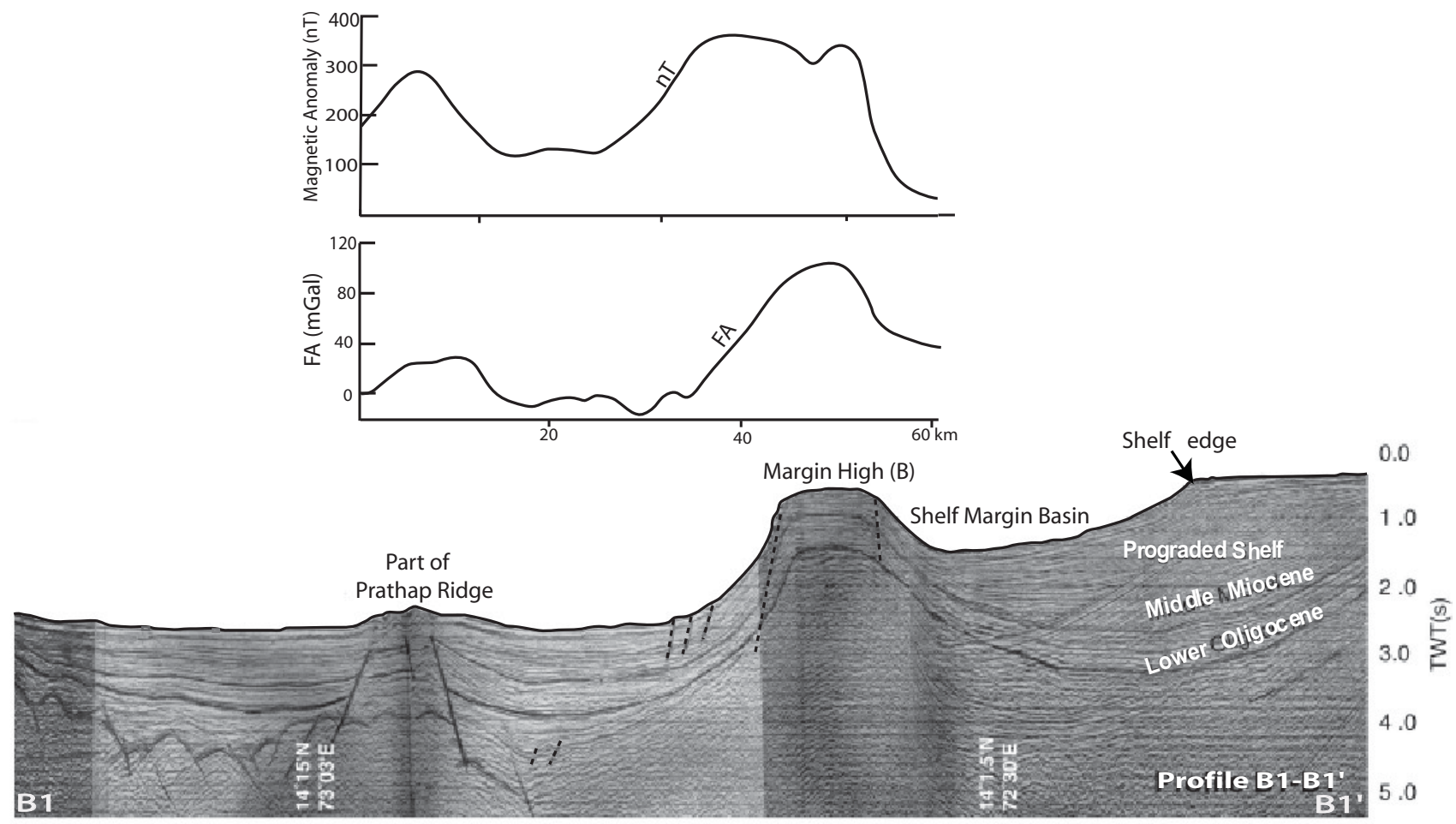

Fig. 6 Gopala Rao et al., 2009 
Figure 7
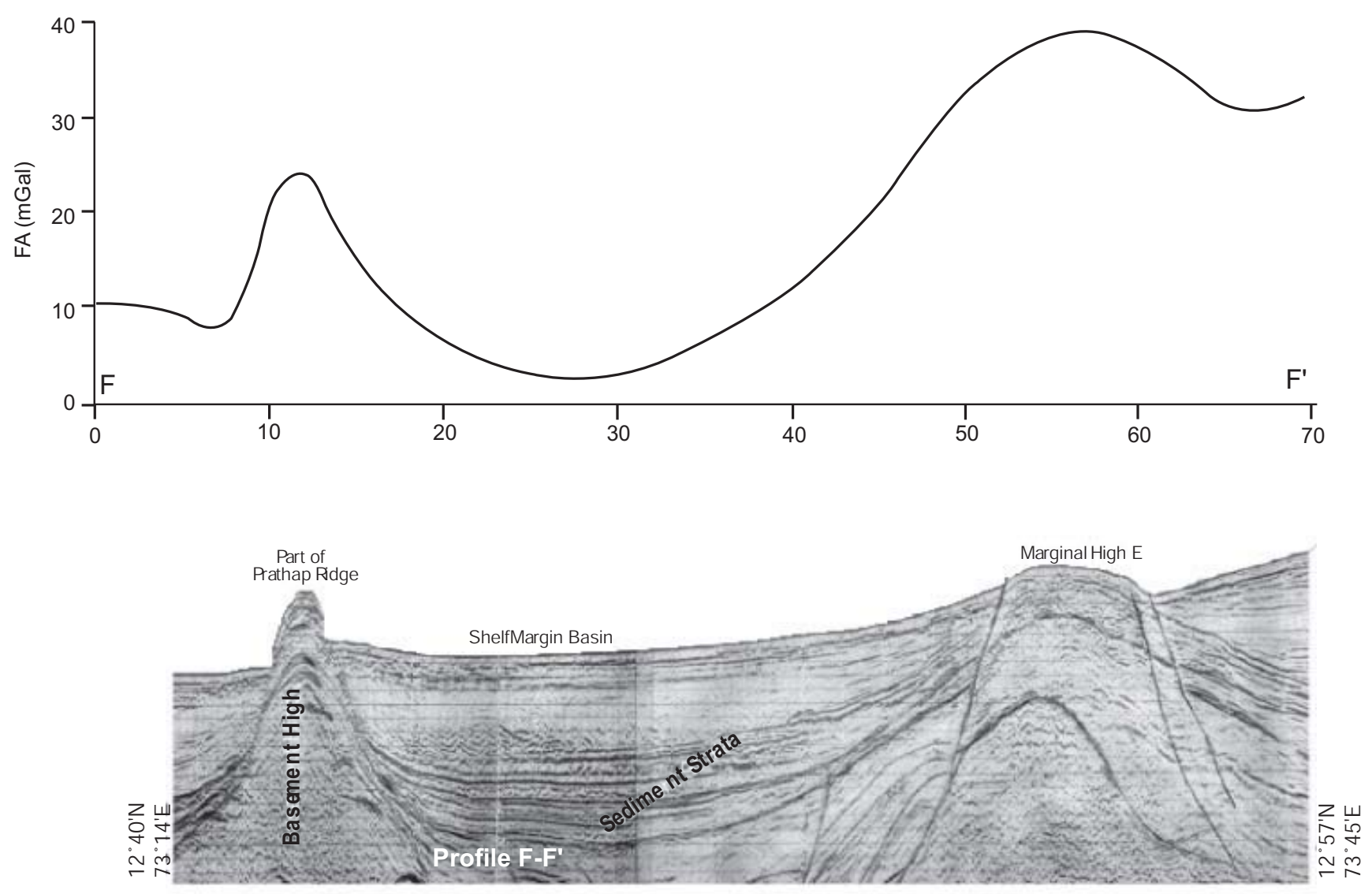

Fig. 7 Gopala Rao et al., 2009 
Figure 8

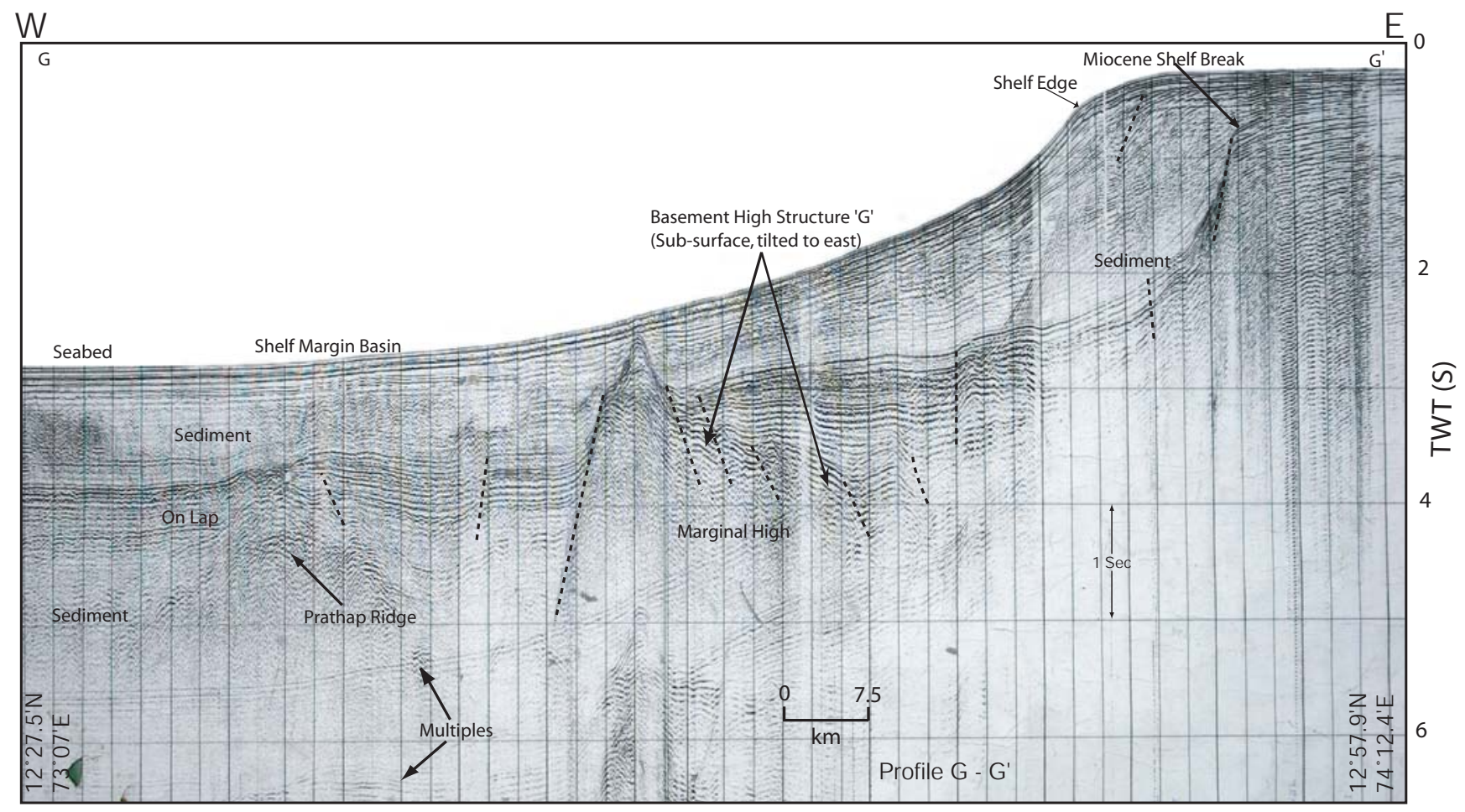

Fig. 8 Gopala Rao et al., 2009 
Figure 9

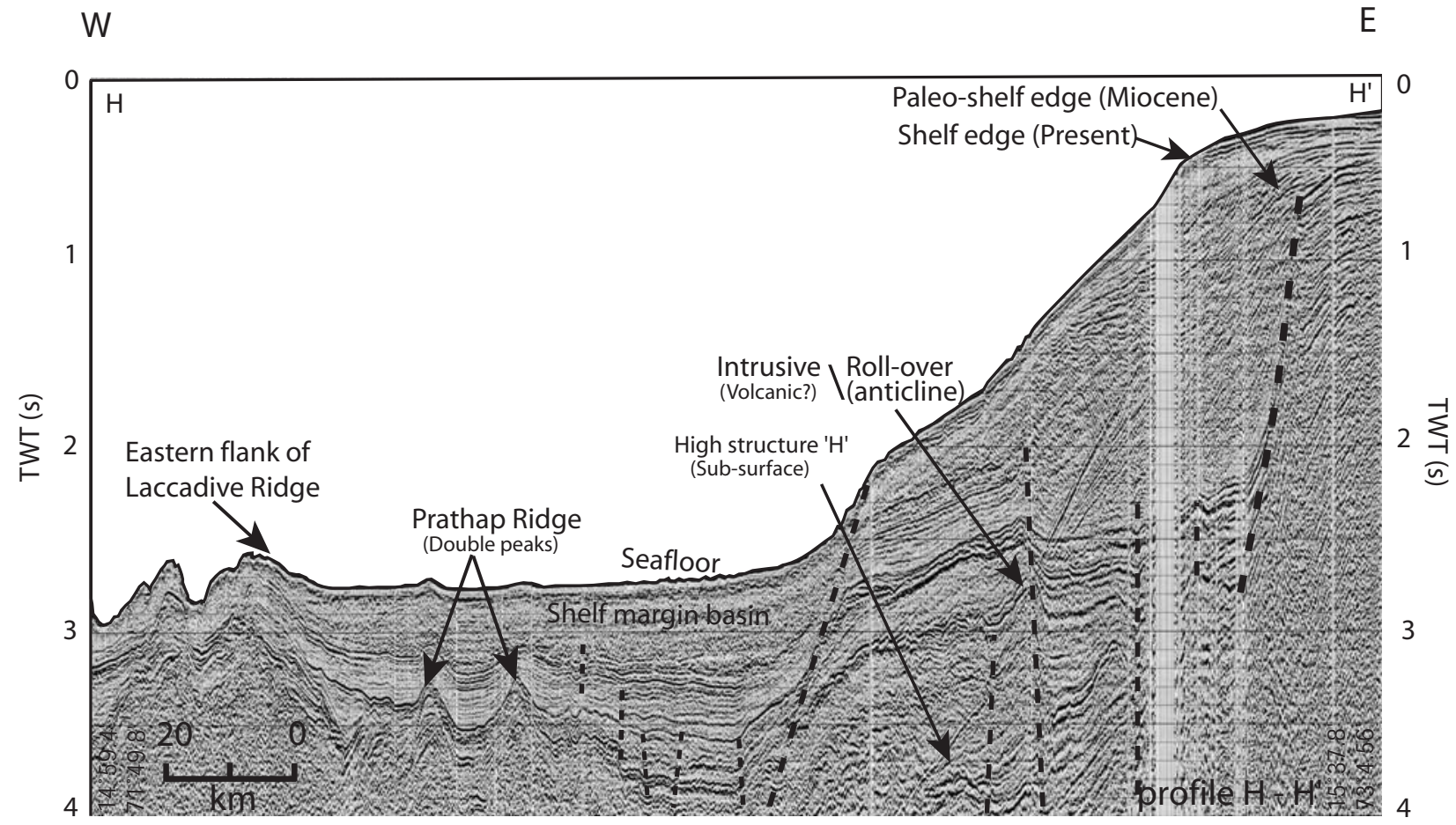

Fig. 9 Gopala Rao et al., 2009 
Figure 10
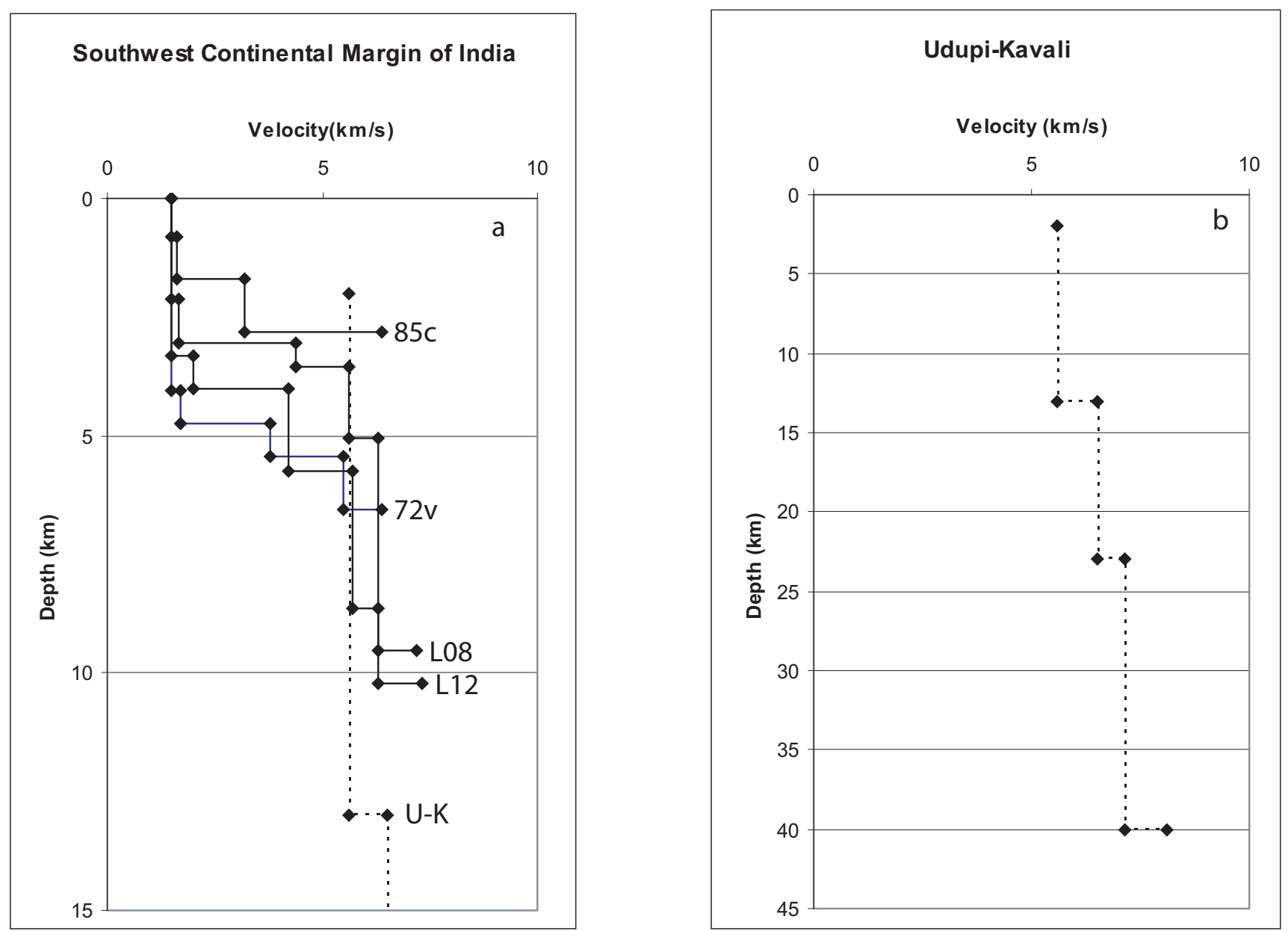

Fig. 10 Gopala Rao et al., 2009 

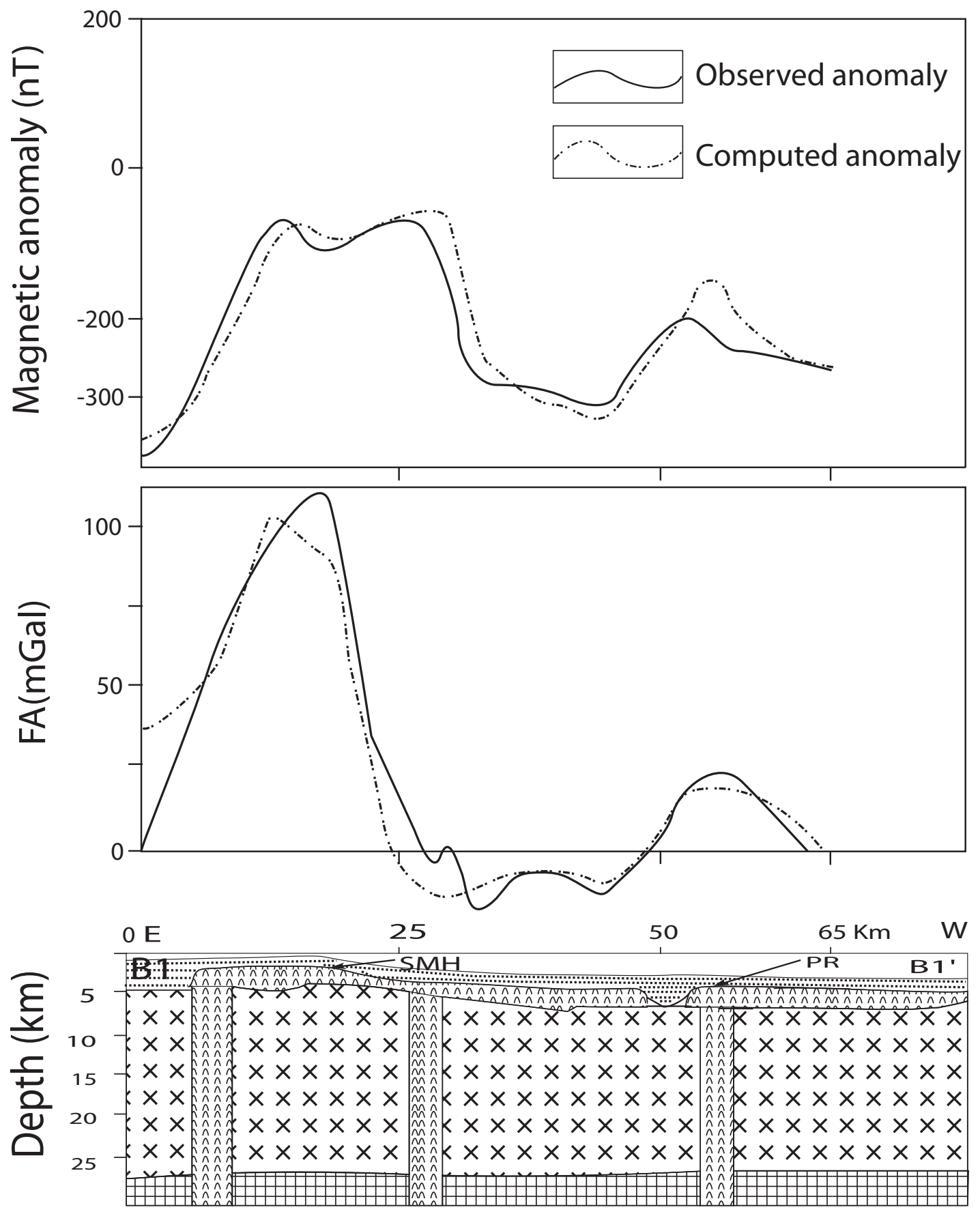

\begin{tabular}{|c|c|c|c|}
\hline & Water $1.03 \mathrm{gm} / \mathrm{cc}$ & & Sediments $2.3 \mathrm{gm} / \mathrm{cc}$ \\
\hline 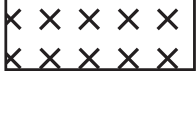 & $\begin{array}{l}\text { Granitic rocks } \\
\text { [ } 2.65 \text { to } 2.92 \mathrm{gm} / \mathrm{cc} \text { ] }\end{array}$ & 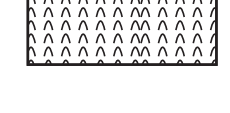 & $\begin{array}{l}\text { Volcanic rocks } \\
\text { (3 to } 6 \mathrm{~A} / \mathrm{m} \text {, magnetzation) }\end{array}$ \\
\hline |\#\#巟 & $\begin{array}{l}\text { Mantle rocks } \\
(3.27 \mathrm{gm} / \mathrm{cc})\end{array}$ & $\begin{array}{l}\mathrm{SMH}=\text { Shel } \\
\mathrm{PR}=\text { Prath }\end{array}$ & $\begin{array}{l}\text { f Margin High } \\
\text { ap Ridge }\end{array}$ \\
\hline
\end{tabular}

Fig. 11 Gopala Rao et al., 2009 


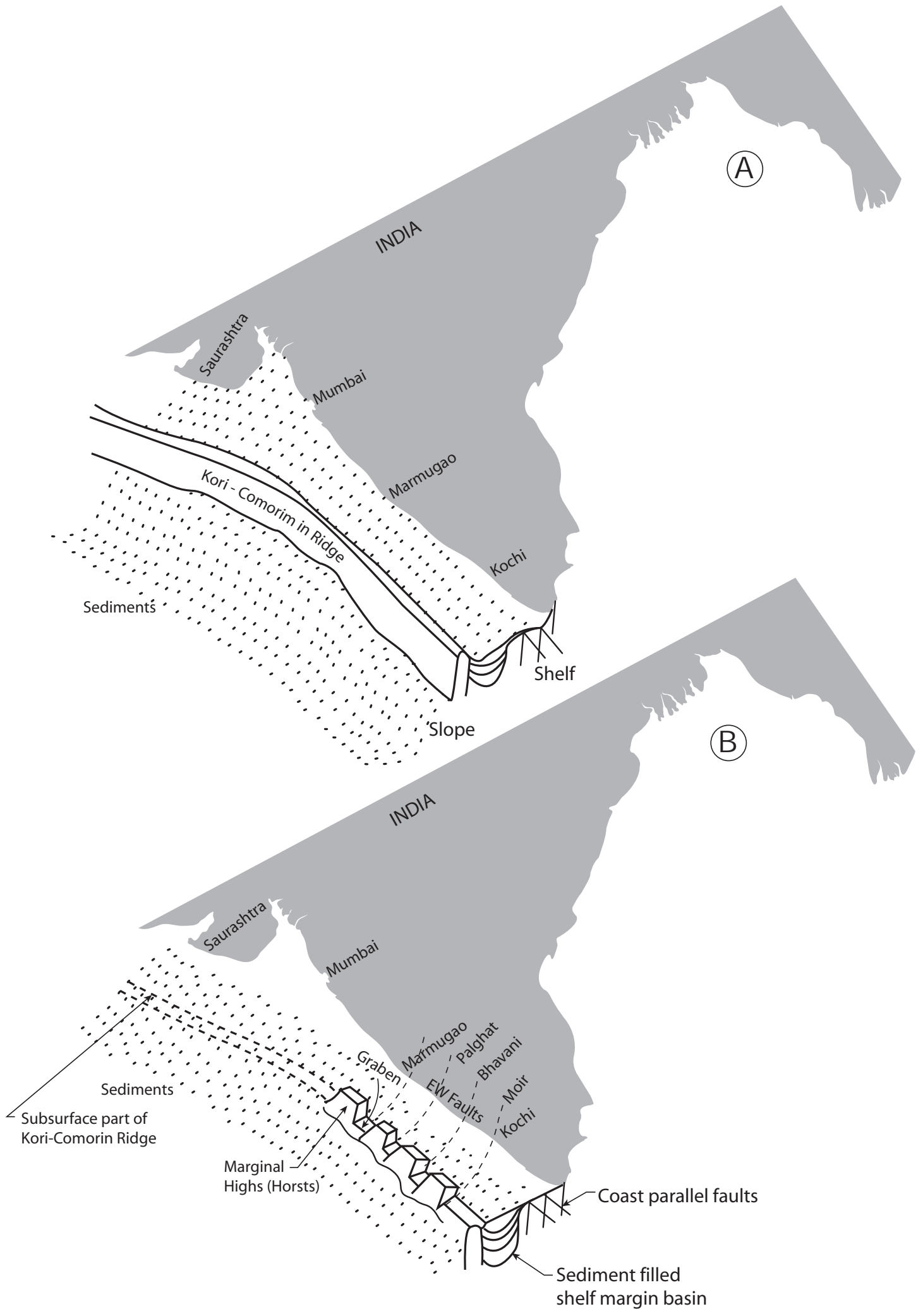

Fig. 12 Gopala Rao et al., 2009 


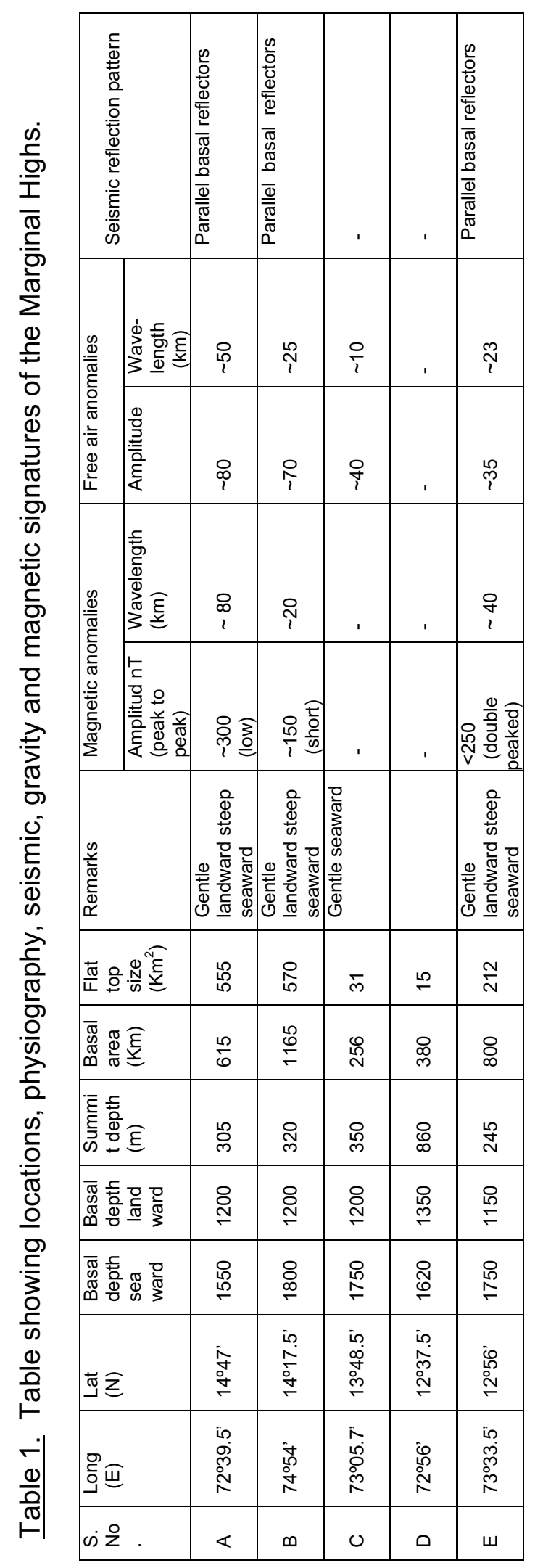




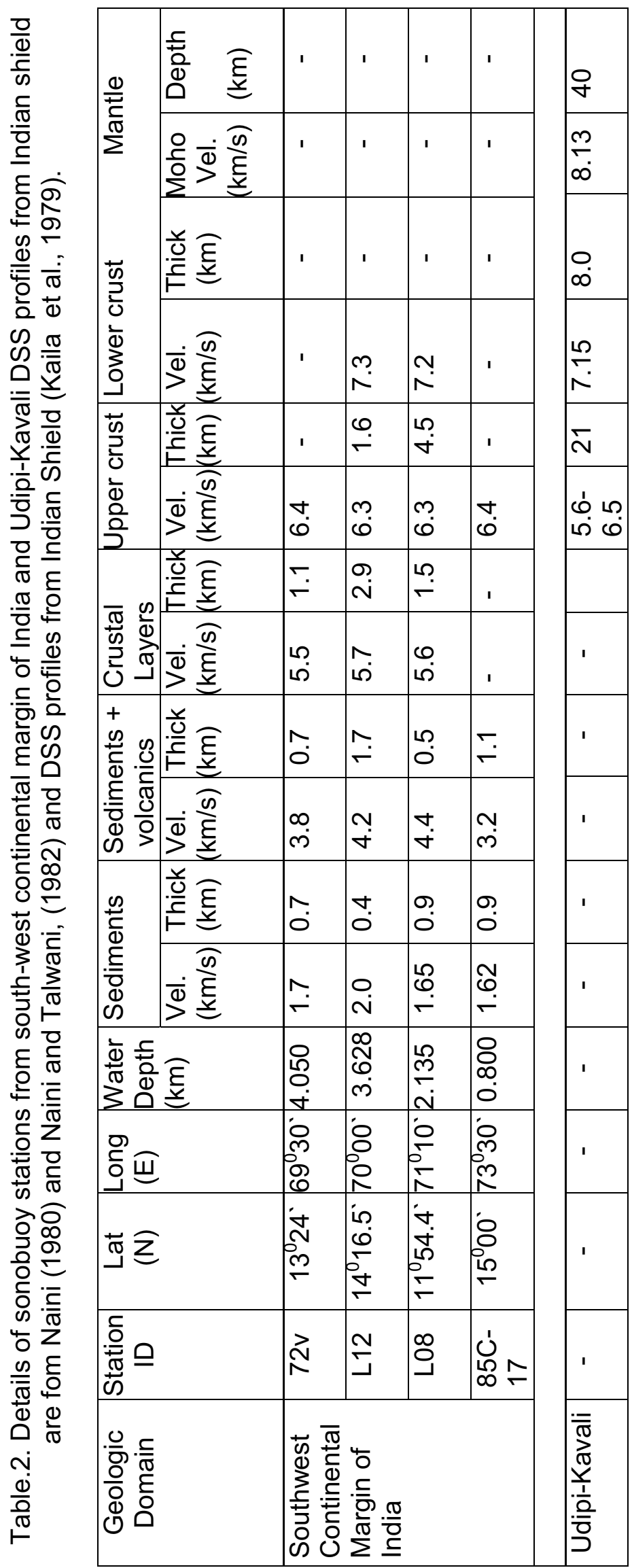

